\title{
ADAPTIVE TESTING SYSTEM BASED ON THE FUZZY LOGIC
}

\author{
${ }^{1,2}$ Aviation Computer-Integrated Complexes Department, Educational\&Scientific Institute of Information- \\ Diagnostics Systems, National Aviation University, Kyiv, Ukraine \\ E-mails: ${ }^{1}$ svm@nau.edu.ua, ${ }^{2}$ alena11_95@mail.ru
}

\begin{abstract}
In this articl, the system analysis of the subject area of the evaluating the test results problem is performed, as a result of which it is classified into clear and fuzzy concepts and relations of the problem, which allowed choosing the fuzzy logic apparatus as the main formalism of the problem solution. Scaling for all linguistic variables of the problem, which allowed to determine their term set reasonably was performed. The fuzzy logic structure was given. The structure of fuzzy logic inference was considered. The principle of constructing fuzzy rules, which allowed to develop production rules for assessing the trainee's knowledge level using specified input and output linguistic variables is considered. The stages of usage fuzzy logic in the knowledge assessment adaptive testing system was considered. Structure of the knowledge assessment system with fuzzy logic was given. The scheme for submitting questions to the trainee is considered. The structure of adaptive testing system using fuzzy logic is developed.The results of applying adaptive testing in the knowledge assessment of the experimental and control groups of trainees are presented. Based on the obtained results, the effectiveness of adaptive testing based of the fuzzy logic in the process of trainee's knowledge assessment is shown.
\end{abstract}

Index Terms - Automated testing system; computer knowledge assessment; adaptive tests: fuzzy logic; fuzzy logic inference.

\section{INTRODUCTION}

Due to the growth of technical progress, one of the main tasks is to improve the quality of teaching new technologies. One of the ways to solve this problem is the widespread use of computer technologies at all stages of training, in particular, in the process of testing knowledge.

To date, the most significant problem in knowledge management systems is the primitive final evaluation calculation. Most often, the number of points for a test task is determined as the ratio of the correct answers number to the proposed answers number, and the total score for the test calculates by simple summation.

At the same time, each issue has some level of complexity, maybe more or less original. It is also necessary to take into account the test task practical importance, since an incorrect answer to a fundamental or practically important question should reduce the overall assessment of the future specialist skills.

The transition from setting the truth of the proposed answers in the categories of binary logic ("correct-incorrect") to a more general and universal estimation scheme, taking into account partially true or incomplete answers, is possible with membership functions defined in categories of fuzzy logic. Such a transition does not deny the traditional approach, because according to modern concepts binary logic can be considered a special case of fuzzy logic. Fuzzy logic is used in common with traditional methods. It makes possible to simplify the creation and expansion of the possibilities of traditional methods.

To increase the accuracy and reliability of evaluating learning outcomes, the use of a fuzzy logic apparatus is proposed.

\section{FUZZY LOGIC STRUCTURE}

A fuzzy logic inference is the approximation of the dependence $Y=f\left(X_{1}, X_{2} \ldots X_{n}\right)$ of each output linguistic variable on the input linguistic variables and obtaining a conclusion in the form of a fuzzy set corresponding to the current input values using a fuzzy knowledge base and fuzzy operations. The basis of fuzzy inference is the compositional Zadeh rule. The structure of the fuzzy model is shown in Fig. 1.

In the general case, a fuzzy logic inference occurs in three (or four) steps.

1) Fuzzification. Conversion of numeric values to the specified fuzzy sets values using their membership functions.

2) Fuzzy logic inference. This stage is a process of transforming input values based on a rule base, which is a set of fuzzy statements presented as IF_ELSE rules, and membership functions for the 
corresponding linguistic terms (natural language phrases). The rules base is considered complete if the following conditions are met:

- for each linguistic term there is at least one rule;
- for any input variable, there is at least one rule where this variable is used in the condition.

3) Defuzzification. Used when it is useful to convert a fuzzy set of linguistic variables inference values to exact values.

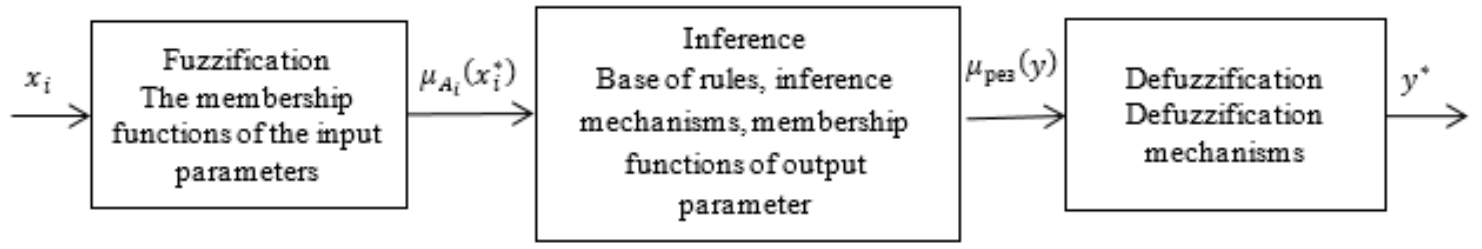

Fig. 1. Fuzzy logic structure

The structure of the fuzzy inference is shown in Fig.2. It consists of several layers, where:

1 layer is the input layer that realizes the test questions. This is the layer of the input variables fuzzification.

2 layer an intermediate layer that implements logical rules. This is the layer of aggregation of the left parts of rules;

3 layer is the output layer, realizing the evaluation in a 12-point scale. This is the layer of defuzzification.

$$
y_{j}=\sum w_{i} x_{i}, i=\overline{1, N}, j=\overline{1,12} .
$$

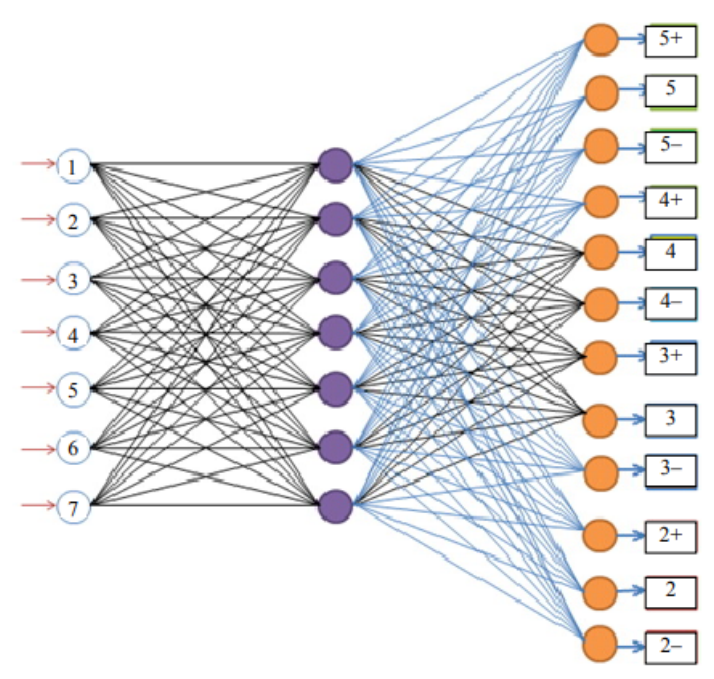

Fig. 2. The structure of fuzzy inference

\section{PROBLEM STATEMENT}

Given test consists of $N$ number of questions. Each question has its own level of complexity and practical significance.

It is necessary to determine the quality of the certain question, which has the following characteristics: the value of "complexity" - 85 and the value of "practical significance" - 50 .

All questions are structured around topics, complexity, importance, which allows to set logic rules for tests of each topic.
Input variables:

- the total number of questions in the test on a certain topic;

- total number of correct answers;

- the number of correct answers for each complexity level.

Output variables:

- trainee's knowledge level;

- test assessment.

The logical rule will be constructed as follows: the trainee's score will be determined depending on the number of questions, the number of correct answers, the number of correct answers for a particular level of complexity.

If the final testing is conducted, which includes questions from different topics with different levels of complexity, then the logical rules will consist of the following evaluation criteria.

Input variables:

- total number of questions;

- total number of topics;

- the number of correct answers on each topic;

- the number of correct answers on each complexity level;

- the number of correct answers on each level of importance (weight of the question).

Output variables:

- trainee's knowledge level;

- test assessment.

If we consider each question separately, where the time for passing the test is limited, then in order to determine the question quality or its cost (evaluation) the following evaluation criteria can be used.

Input variables:

- level of question complexity;

- the practical importance of the test task (weight);

- question answering time. 
Output variables:

- trainee's knowledge level;

- test assessment.

The fuzzy approach in control testing of the trainee's knowledge allows using the fuzzy logic device as an effective means of setting up assessments process automating, which occurs at the stage of defuzzification.

\section{PROBLEM SOLUTION}

The quality of test tasks is determined by many factors: relevance, complexity, originality, practical significance, accuracy. The most important of them are complexity and practical significance.

Therefore, it is necessary to define the following linguistic variables: "complexity" $S$ and "practical significance" $Z$.

Points for $S$ are summed up in the following positions: the number of the answer variants, the complexity of the question, the need to perform additional calculations for the answer, the total amount of questioning and answer variants.

Points for $Z$ are summed up according to the following positions: the fundamental nature of the question, the applicability of the question in practice, the importance of giving the correct answer on the proposed test task.

The maximum number of points for each position is determined in advance.

For both linguistic variables $S$ and $Z$ the term set ("low", "intermediate", "high") is given. The membership functions for terms are shown in Figs 3 and 4.
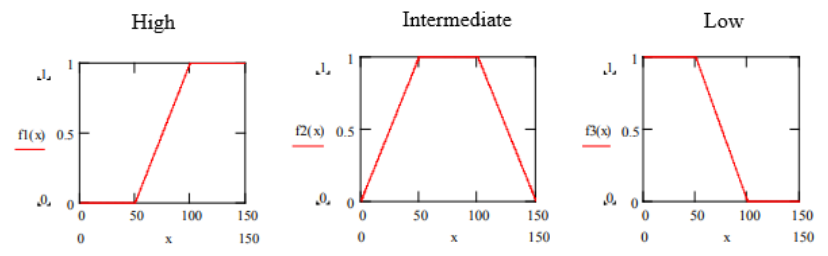

Fig. 3. Membership function of the "complexity" linguistic term
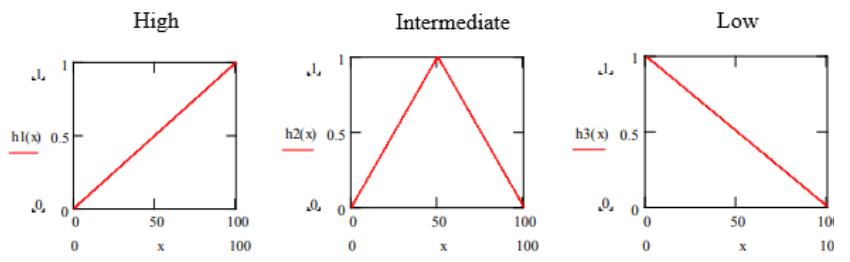

Fig. 4. Membership function of the "practical significance" linguistic term

The output variable is $k$ is the quality factor of the question, which is determined in the range from two to eight. The number of points scored by the trainee for answering the question is multiplied by the coefficient $k$ numerical value. Thus, different questions have different maximum possible number of points scored. Naturally, when the overall score is given, the number of points scored by the trainee must be correlated with the total maximum possible number of points scored.

The term set for variable $k$ is given in the form \{"High", "Intermediate", "Low"\} (Fig. 5).

It is possible to write the inference rules in the Mamdani form:

IF $\mathrm{S}$ is "low" and $Z$ is "low" THEN $k$ is "high",

IF $\mathrm{S}$ is "intermediate" and $Z$ is "intermediate" THEN $k$ is "intermediate",

IF $\mathrm{S}$ is "high" and $Z$ is "high" THEN $k$ is "low".
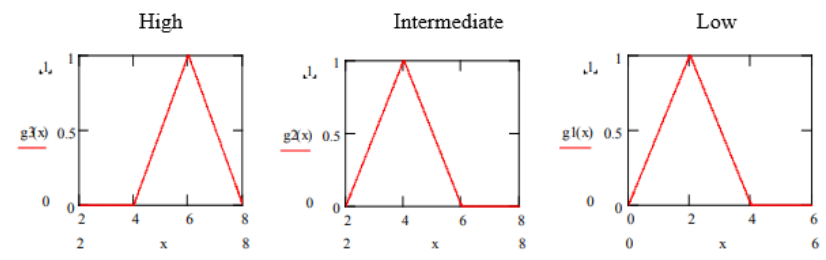

Fig. 5. Membership function of the "quality coefficient" linguistic term

We will calculate the value of the quality factor.

Consistently consider the stages of fuzzy inference:

1) Firstly, from the given values of the input parameters, it is necessary to find the confidence levels of the simplest statements of the form "Linguistic variable $A$ is Term of linguistic variable $A$ ". This stage is called fuzzification, i.e. transition from specified values to confidence levels.

The following confidence levels are given:

- high complexity -0.7 ;

- intermediate complexity - 1;

- low complexity - 0.3;

- high practical significance -0.5 ;

- intermediate practical significance -1 ;

- low practical significance -0.5 .

Then it is necessary to calculate the confidence level in the premises of the rules:

- Low complexity and Low practical significance:

$$
\min (0.3,0.5)=0.3 \text {. }
$$

- Intermediate complexity and Intermediate practical significance:

$$
\operatorname{avg}(1,1)=1
$$

- High complexity and High practical significance:

$$
\max (0.7,0.5)=0.7
$$

It should also be noted that, with the help of transformations of fuzzy sets, any rule that contains both a conjunction and a disjunction on the left-hand side can be reduced to a system of rules, on the left 
side of each one there are either only conjunctions or only disjunctions. Thus, without loss of generality, we can consider rules containing on the left-hand side either only conjunctions or only disjunctions. Each of the rules is a fuzzy implication.

2) The confidence level of the conclusion is determined by the membership function of the corresponding term. Therefore, using one of the constructing a fuzzy implication methods, it is possible to get a new fuzzy variable corresponding to the confidence level about the output variable value when applying the corresponding rule to the given input. Using the definition of fuzzy implication as a minimum of the left and right parts, we have:


Fig. 6. Rules for output value

3) Now it is necessary to combine the results of applying all the rules. This stage is called accumulation (Fig. 7). One of the main ways of accumulation is to build the maximum of the obtained membership functions.

As a result, the following structure is obtained.

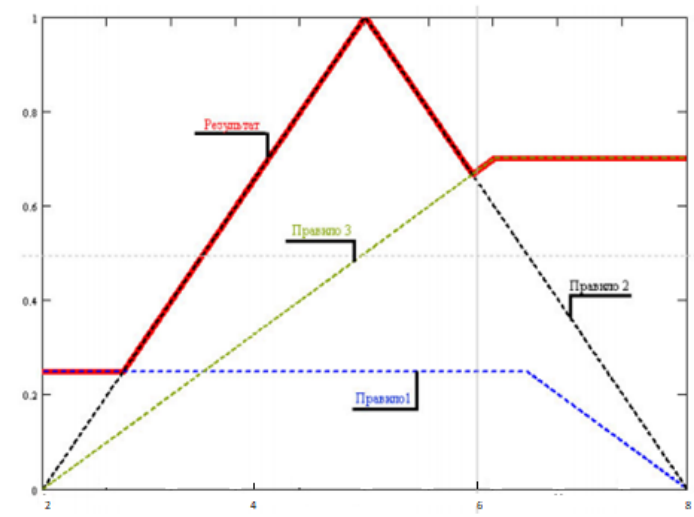

Fig. 7. Accumulation

The obtained membership function can already be considered as a result. This is the new term of the quality factor output variable. Its membership function indicates the confidence level in the quality factor value for given values of input parameters and rules that determine the ratio of input and output variables. But usually it's still necessary to have a specific numerical value.

4) To obtain it, the defuzzification stage is used, i.e. obtaining a specific value from the university by the membership function specified on it. There are many methods of defuzzification, but in our case, the first maximum method is sufficient. Applying it to the received membership function, we get that the value of the quality factor is 5 .

Therefore, it is possible to determine the stages of decision-making under conditions uncertainty using the Mamdani algorithm:

1) the selection of factors, on the basis of which a decision will be made. For each factor, set its values (term-set), define the membership functions for each linguistic term from the basic term-set. In addition, it determines the level of confidence for each rule;

2) calculation of each rules outputs using the operation of a minimum;

3 ) the union of all fuzzy sets obtained at the rules output, using the operation of the maximum in a single fuzzy set;

4) the transition from a fuzzy set to a specific value (if necessary).

Thus, the use of the fuzzy logic inference for decision-making has the following advantages: the ability to operate with fuzzy input data, fuzzy formalization of evaluation and comparison criteria.

Testing assessment system is implemented using a fuzzy logic method to assess the trainee's knowledge.

The structure of the knowledge assessment system which is implemented using a fuzzy logic is represented on the Fig. 8.

- Testing subsystem - implements the interface of the trainee and the adaptive knowledge assessment system interaction.

- A block of disciplines is a subsystem responsible for filling in and storing information about disciplines, the interrelations between subjects of disciplines and determining the degree of importance of a topic.

- The adaptive tests formation subsystem allows to set the required level of quality of the created tests and determine the values of the parameters of the test being created.

- Base of questions - repository of questions on a given topic. Through the interface of the adaptive tests formation subsystem, the administrator gets the opportunity to form test questions of various types, to determine the relationships between them, to set the positive or negative weight of each answer to the formulated question.

- Knowledge base - is a fuzzy knowledge base that allows to evaluate the answer to each test task and the control task as a whole.

- The subsystem of knowledge assessment based on fuzzy logic - allows to adequately assess the knowledge of the trainee taking into account the quality of the test, the level of theoretical and practical knowledge of the trainee for each topic and in general throughout the course. 
- Database of test results. All test results are saved and used in the preparation of analytical reports on trainees' progress.

The basis of the knowledge testing system is the subsystem of intelligent knowledge assessment based on fuzzy logic. The system is implemented in two levels.

At the first level, the trainee's knowledge assessment is made on each topic separately, on the second level, a final assessment is formed.
When the trainee passes the test, not only the basic questions that are the basis of the "ideal" test are taken into account, but also a $\mathrm{B}_{\mathrm{i} 2}$ question similar to the question $\mathrm{B}_{\mathrm{i} 1} ; \mathrm{B}_{\mathrm{i} 3^{-}}$leading question; $\mathrm{B}_{\mathrm{i} 4^{-}}$the question of minimal difficulty, so the number of points on the $i$ th level of complexity is usually less than $R_{i}$ (Fig.9). This achieves adaptation to the determining of the trainee's knowledge level. The trainee loses points in cases of incorrect or inaccurate answers, so the final score for the test may differ from 100.

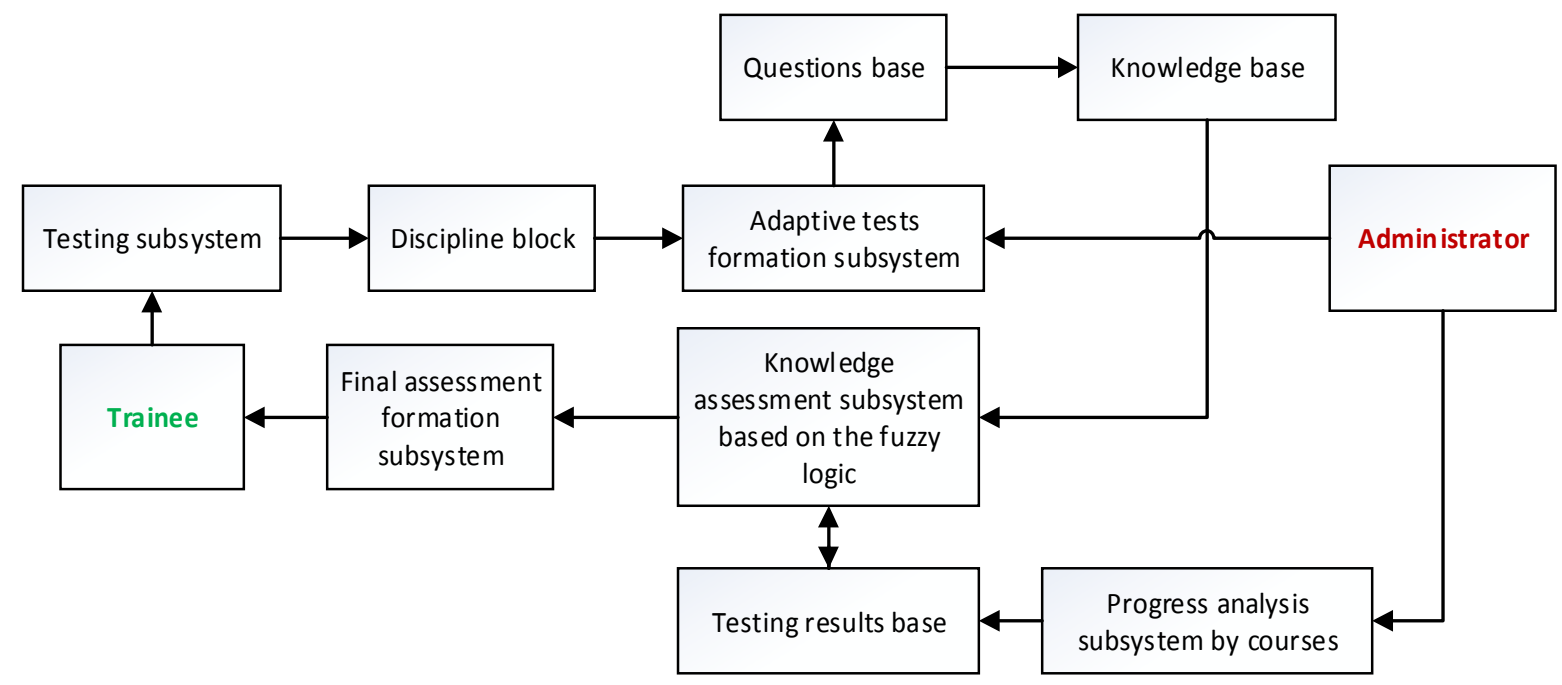

Fig. 8. Structure of the knowledge assessment system with fuzzy logic

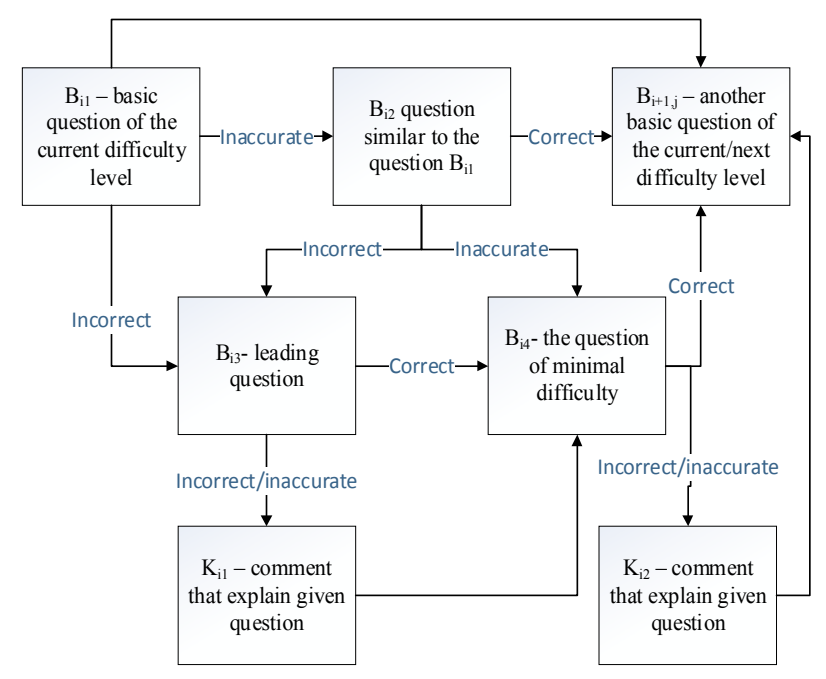

Fig. 9. Sequence of submitting questions

\section{RESULTS}

Statistical data of a computerized testing system showed that with the systematic application of testing in knowledge assessment, the level of knowledge of learners is increased.

To check the effectiveness of the computer adaptive testing system, an experiment was conducted to compare the level of knowledge quality of learners with traditional and computer-based assessment.

The results of the assessment of knowledge in traditional testing, which was conducted in two groups - control and experimental are in [8].

To check the effectiveness of using the adaptive testing system, in the control group knowledge assessment was conducted by means of traditionally testing, and the experimental group used the computer system to assess the level of knowledge. The results are shown in [8].

Based on the presented experimental data, it can be concluded that the use of computer adaptive testing increases the training characteristics such as:

- efficiency: significantly fewer tasks are required to assess the level of preparedness of the subject;

- accuracy: the ability to assess the level of preparedness of each subject at his level with a minimum measurement error;

- reduced probability of guessing the correct answer;

- learners do not spend time and effort on tasks that do not correspond to their level of preparation (too easy for them or too difficult), therefore the influence on the results of additional factors (fatigue, anxiety, inaccuracy) decreases; 
- the learners are more motivated and calm (because they are not offered tasks, which are too difficult for them).

\section{CONCLUSION}

Computer testing allows to use additional features when developing tasks and administering them in comparison with traditional blank testing. Thanks to adaptive testing using fuzzy logic, each trainee gets his own set of tasks, so both the content and length of the test can differ for different trainees, each trainee is assessed individually (at his level) with a minimum measurement error.

Assignments that adaptive computer testing based on the fuzzy logic offers the trainee become more complicated gradually and ideally fit his or her knowledge and skills at each moment of testing, increasing the motivation to pass the test.

\section{REFERENCES}

[1] Andrew Fluck, Darren Pullen and Colleen Harper, "Case study of a computer based examination system," Australasian Journal of Educational Technology, no. 25(4), pp. 509-523, 2009.

[2] C. Elena, Papanastasiou, Computer Adaptive testing in science education / [Electronic source]
http://cblis.utc.sk/cblisdold/2003/3.PartB/Papers/Scie nceEd/TestingAssessment/Papanastasiou.pdf

[3] "TestMaker" testing system [Electronic source] http://www.pushtotest.com/products.

[4] "Indigo" testing system [Electronic source] https://indigotech.ru

[5] L. N. Radvanskaya, and Yu. V. Chepurnaya, "Algorithm for constructing a computerized adaptive knowledge testing system for trainees," System information boxes, Issue 5(72), pp. 182-185, 2008. (in Russian)

[6] S. V. Duplik, "Model of adaptive testing on fuzzy mathematics," Kazan State Technical University them. AN Tupolev, 2016. (in Russian)

[7] K. A. Goncharova, V. S. Dobryak, and M. S. Mazorchuk, "Knowledge control system based on adapted testing technology," Problems and prospects of IT industry development in Ukraine: International science-practice Conf., 18-19 November 2009. : Collection of abstracts. Kharkiv: KhNUE Publishing House, 2009, pp. 266-268. (in Ukrainian)

[8] V. M. Sineglazov and A. V. Kusyk, "System of Adaptive Tasks Selection in the Testing Process," Electronics and Control Systems, no. 1(55), Kyiv: NAU, pp. 47-52, 2018.

Received March 12, 2018

Sineglazov Victor. Doctor of Engineering Science. Professor.

Aviation Computer-Integrated Complexes Department, Education\&Scientific Institute of Information-Diagnostics Systems, National Aviation University, Kyiv, Ukraine.

Education: Kyiv Polytechnic Institute, Kyiv, Ukraine, (1973).

Research area: Air Navigation, Air Traffic Control, Identification of Complex Systems, Wind/Solar power plant.

Publications: more than 600 papers.

E-mail:svm@nau.edu.ua

Alona Kusyk. Master.

Aviation Computer-Integrated Complexes Department, Education\&Scientific Institute of Information-Diagnostics Systems, National Aviation University, Kyiv, Ukraine.

Education: National Aviation University, Kyiv, Ukraine, (2016).

Research interests: automated testing systems.

Publications: 2.

E-mail: alena11_95@mail.ru

\section{В. М. Синєглазов, А. В. Кусик. Система адаптивного тестування на основі нечіткої логіки}

Проведено системний аналіз предметної області оцінки проблеми результатів випробувань, в результаті чого його можна класифікувати на чіткі і нечіткі концепції, що дозволяє вибирати пристрій нечіткої логіки в якості основного рішення проблеми. Виконано масштабування для всіх лінгвістичних змінних проблеми, що дозволило визначити набір термів. Дана структура нечіткої логіки. Розглянуто структуру логічного виводу нечіткої логіки. Розглянуто принцип побудови нечітких правил, що дозволяє розробляти продукційні правила для оцінки рівня знань учня з використанням заданих вхідних і вихідних лінгвістичних змінних. Розглянуто етапи використання нечіткої логіки в системі адаптивного тестування знань. Дана структура системи оцінки знань 3 нечіткою логікою. Розглянуто схему подачі питань слухачеві. Розроблено структуру адаптивної системи тестування 3 використанням нечіткої логіки. Представлені результати застосування адаптивного тестування в оцінці знань експериментальної і контрольної груп учнів. На основі отриманих результатів показана ефективність адаптивного тестування на основі нечіткої логіки в процесі оцінки знань учня.

Ключові слова: автоматизована система тестування; оцінка комп'ютерних знань; адаптивні тести; нечітка логіка; нечіткий логічний висновок. 
Синсглазов Віктор Михайлович. Доктор технічних наук. Професор.

Кафедра авіаційних комп'ютерно-інтегрованих комплексів, Навчально-науковий інститут інформаційнодіагностичних систем, Національний авіаційний університет, Київ, Україна.

Освіта: Київський політехнічний інститут, Київ, Україна (1973).

Напрям наукової діяльності: аеронавігація, управління повітряним рухом, ідентифікація складних систем, вітроенергетичні установки.

Кількість публікацій: більше 600 наукових робіт.

E-mail:svm@nau.edu.ua

Кусик Альона Вікторівна. Магістр.

Кафедра автоматизації та комп'ютерно-інтегрованих технологій, Навчально-науковий інститут інформаційнодіагностичних систем, Національний аваційний університет, Київ, Україна.

Освіта: Нацональний авіаційний університет, Київ, Україна (2016).

Напрям наукової діяльності: автоматизовані системи тестування.

Кількість публікацій: 2.

E-mail: alena11_95@mail.ru

В. М. Синеглазов, А. В. Кусик. Система адаптивного тестирования на основании нечеткой логики

Проведен системный анализ предметной области оценки проблемы результатов испытаний, в результате чего его можно класифицировать на четкие и нечеткие концепции, что позволяет выбирать устройство нечеткой логики в качестве основного решения проблемы. Выполнено масштабирование для всех лингвистических переменных проблемы, что позволило определить набор термов. Дана структура нечеткой логики. Рассмотрена структура логического вывода нечеткой логики. Рассмотрен принцип построения нечетких правил, позволяющий разрабатывать продукционные правила для оценки уровня знаний обучаемого с использованием заданных входных и выходных лингвистических переменных. Рассмотрены этапы использования нечеткой логики в системе адаптивного тестирования знаний. Дана структура системы оценки знаний с нечеткой логикой. Рассмотрена схема подачи вопросов слушателю. Разработана структура адаптивной системы тестирования с использованием нечеткой логики. Представлены результаты применения адаптивного тестирования в оценке знаний экспериментальной и контрольной групп обучаемых. На основе полученных результатов показана эффективность адаптивного тестирования на основе нечеткой логики в процессе оценки знаний обучаемого.

Ключевые слова: автоматизированная система тестирования; оценка компьютерных знаний; адаптивные тесты; нечеткая логика; нечеткий логический вывод.

Синеглазов Виктор Михайлович. Доктор технических наук. Профессор.

Кафедра авиационных компьютерно-интегрированных комплексов, Учебно-научный институт информационнодиагностических систем, Национальный авиационный университет, Киев, Украина.

Образование: Киевский политехнический институт, Киев, Украина (1973).

Направление научной деятельности: аэронавигация, управление воздушным движением, идентификация сложных систем, ветроэнергетические установки.

Количество публикаций: более 600 научных работ.

E-mail: svm@nau.edu.ua

Кусик Алена Викторовна. Магистр.

Кафедра автоматизации и компьютерно-интегрированных технологий, Учебно-научный институт информационно-диагностических систем, Национальный авиационный университет, Киев, Украина.

Образование: Национальный авиационный университет, Киев, Украина (2016).

Направление научной деятельности: автоматизированные системы тестирования.

Количество публикаций: 2.

E-mail: alena11_95@mail.ru 